\title{
BIBLIOMETRIJSKE ZNAČAJKE KATEGORIZIRANIH RADOVA ČASOPISA MEDIJSKA ISTRAŽIVANJA (1995.-2015.)
}

\author{
BIBLIOMETRIC FEATURES OF CATEGORIZED \\ ARTICLES: THE JOURNAL MEDIJSKA ISTRAŽIVANJA/ \\ MEDIA RESEARCH (1995-2015)
}

\author{
Kristina Romić \\ kromic@nsk.hr \\ Goranka Mitrović \\ gmitrovic@nsk.hr \\ Nacionalna i sveučilišna knjižnica u Zagrebu
}

UDK / UDC 001.8:[050:070]“1995/2015“

Stručni rad / Professional paper

Primljeno / Received: 5.6. 2017.

Prihvaćeno / Accepted: 2.11.2017.

\section{SAŽETAK}

Cilj. U radu se analizira znanstveno-stručni časopis za novinarstvo i medije Medijska istraživanja tijekom dva desetljeća njegova izlaženja. Ovaj rad ima za cilj na osnovi određenih bibliometrijskih pokazatelja dobiti uvid u razvoj tog časopisa tijekom dvadesetjednogodišnjeg izlaženja te utjecaj časopisa na znanstvenu zajednicu.

Metodologija. Uzorak za istraživanje činili su svi brojevi časopisa od 1995. do 2015. godine s ukupno 276 kategoriziranih radova, na kojima je provedena bibliometrijska analiza. Analizirali su se podatci o dinamici izlaženja, autorstvo, jezik te prisutnost $\mathrm{i}$ indeksiranost časopisa u međunarodnom e-okruženju.

Rezultati. Dobiveni rezultati pokazuju da su najzastupljeniji izvorni znanstveni radovi (46\%). Autori koji su objavljivali u Medijskim istraživanjima uglavnom su iz Hrvatske $(59,7$ \%) ili iz zemalja regije (Hrvatska i ostale države nastale raspadom bivše

Vjesnik bibliotekara Hrvatske 60, 4(2017), 197-220

ISSN 0507-1925

(c) VBH 2017. 
Jugoslavije), pa je tako na 60,3 \% kategoriziranih radova s više autora barem jedan autor iz Hrvatske, a na 20,6 \% kategoriziranih radova s više autora barem jedan autor iz regije. Ti podatci ukazuju na jaku nacionalnu, odnosno regionalnu orijentaciju časopisa, što se može pripisati jeziku objavljivanja, koji je većinom hrvatski (60,5 \%). Citatna analiza časopisa provedena je na podatcima o citiranim objavljenim izvornim znanstvenim i preglednim radovima u Clarivate Analyticsovoj (do 2016. godine Thomson Reuters) citatnoj kolekciji Web of Science Core Collection (WoSCC) preko opcije Cited Reference Search koja omogućuje provjeru citiranosti i onih časopisa koji nisu zastupljeni u citatnim indeksima WoSCC te na podatcima o citiranosti indeksiranih radova u citatnoj bazi podataka Scopus. Istraživanje je usmjereno na broj i vrstu citata koje su dobili radovi objavljeni u časopisu Medijska istraživanja. Provedena je i analiza citiranih referenci u WoSCC-u te su utvrđeni podatci o količini citiranih jedinica i nazivu, tj. porijeklu časopisa koji su citirali radove iz časopisa Medijska istraživanja, a također su analizirani autori koji su citirali radove Medijskih istraživanja. Utvrđeno je da su 52 rada časopisa Medijska istraraživanja u srpnju 2016. dobila 89 citata, a izračunati h-indeks iznosio je 4. Citatna analiza zastupljenih radova u Scopusu (razdoblje od 2011. do 2015.) pokazuje da je od 71 indeksiranog rada citirano njih $16 \mathrm{~s}$ ukupnom citiranošću od 29 citata i h-indeksom 3, promatrano u srpnju 2016.

Vrijednost. Rezultati dobiveni ovim istraživanjem mogli bi poslužiti kao smjernice za razvoj časopisa.

Ključne riječi: analiza radova, bibliometrijski pokazatelji, bibliometrijska analiza, znanstveni časopisi

\begin{abstract}
Purpose. The paper analyzes the scientific journal dealing with journalism and media Medijska istraživanja/Media Research during the two decades it has been published (1995-2015). The purpose of this paper is to present the development of the journal during the twenty-one years of publication and the influence of the journal on the scientific community by showing the results of certain bibliometric indicators.

Methodology.The research sample included all published issues of the journal in the period from 1995 to 2015 with a total of 276 papers, which were subjected to bibliometric analysis. The paper analyzes the development of the journal over the researched period focusing on categories such as publication dynamics, language, contributing authors, as well as presence and citation in many international abstract and citation databases.
\end{abstract}

Findings. The results of the analysis have shown that, for the most part, the original scientific papers $(46 \%)$ have been published in the journal. The authors of the papers published in the journal Medijska istraživanja/Media Research, come mostly from Croatia $(59.7 \%)$ or the countries in the region (Croatia and other countries of the former Yugoslavia). Furthermore, the analysis have shown that out of $60.3 \%$ categorized articles written by several authors at least one of the authors comes from Croatia, and out of $20.6 \%$ cate- 
gorized works by more than one author, at least one author comes from the region. These data reveal a strong national or regional orientation of the journal, which can be attributed to the language of publication, which is mostly Croatian (60.5\%).

The analysis has shown that the largest number of articles were original scientific papers $(46 \%)$, followed by professional papers $(18.5 \%)$, scientific review papers $(14.9 \%)$, conference papers $(12.3 \%)$, preliminary reports $(6.2 \%)$, retained articles $(1.1 \%)$, and translated works $(1.1 \%)$. The language of the published articles is most often Croatian $(60.5 \%)$. The authors are mostly Croatian (59.8\%) and they come mainly from the higher education institutions, foreign (35.2\%) and domestic (33.2\%). The journal citation analysis was conducted on data from the references cited in the Clarivate Analytics (the Thomson Reuters until 2016) citation collection Web of Science Core Collection (WoSCC), which also allows checking the citations of those journals that are not represented in the citation indexes WoSCC and the citation data of the works indexed in bibliographic and citation database Scopus. The research was focused on the number and type of citations the papers published in the journal Medijska istraživanja/Media Research have received. The analysis of the references cited in WoSCC has shown the total amount of the quoted data units and the names, i.e. the origin (countires) of the journals in which the works from the journal Medijska istraživanja/Media Research were quoted. The results have shown that 52 papers from Medijska istraživanja/Media Research received 89 quotations in July 2016, and the calculated h-index was 4. The citation analysis of the indexed papers from 2011 to 2015 in Scopus showed that out of the 71 indexed works, 16 of them were cited, with the total of 29 citations and the h-index 3 as the records for July 2016 show.

Value. The results of this study could serve as guidelines for the future development of the journal.

Keywords: bibliometric indicators, citation analysis, paper analysis, scientific journals

\section{Uvod}

Znanstveno komuniciranje dinamičan je sustav čiji su elementi dio neprekinutog niza aktivnosti koji za cilj imaju prijenos znanstvenih informacija unutar sustava znanosti, ali i izvan njega. ${ }^{1}$ Napredak i razvitak znanosti nezamislivi su bez komunikacije među znanstvenicima. Komunikacija, formalna ili neformalna, mora postojati kako bi znanost mogla napredovati temeljeći se na pouzdanim prethodnim saznanjima znanstvenika. ${ }^{2}$ Znanstveni i stručni časopisi osnova su znanstvene komunikacije i jedan od glavnih izvora novih znanstvenih ideja. Uloga časopisa u znanstvenoj komunikaciji odvija se kroz produkciju, konzumaciju i diseminaciju znanstvenih i stručnih informacija relevantnoj znanstvenoj javnosti.

\footnotetext{
1 Vrana, R. Vrednovanje znanstvenog rada. // Vjesnik bibliotekara Hrvatske 54, 1-2(2011), str. 173.

2 Hebrang Grgić, I. Kriza izdavaštva znanstvenih časopisa. // Vjesnik bibliotekara Hrvatske 47, 1-2(2004), str. 88.
} 
Prvi znanstveni časopisi počeli su izlaziti 1665. godine (Journal des Sçavans i Philosophical Transactions of the Royal Society) i do danas su ostali konceptualno neizmijenjeni. Časopisi su se u razdoblju od preko 300 godina, koliko postoje, pokazali osobito uspješnima u promicanju znanstvene komunikacije, aktivnosti kojom se znanstveniku pojedincu omogućuje da informira kolege o vlastitim spoznajama, a njima se također omogućuje da na isti način informiraju pojedinca koji je objavio svoje otkriće o rezultatima njegova rada. Kroz razvoj pojedinog časopisa moguće je popratiti razvoj i utjecaj pojedine znanstvene discipline, kao i razvoj te profesionalne zajednice kojoj je časopis namijenjen u cjelini. Pojava znanstvenog časopisa najčešće je znak postojanja određenog većeg broja znanstvenika i stručnjaka koji imaju potrebu artikulirati određenu znanstvenu i stručnu problematiku te ju podijeliti s relevantnom akademskom zajednicom. ${ }^{3}$ Znanstvena komunikacija kao proces stvaranja, korištenja i širenja informacija podložna je promjenama, uvjetovanima i prirodom same znanosti i tehničkim dostignućima. Kraj 20. i početak 21. stoljeća označila je pojava brojnih elektroničkih publikacija i institucijskih izvora informacija poput digitalnih knjižnica i digitalnih repozitorija koji su postavili temelje za snažniji razvoj znanstvene komunikacije u elektroničkoj okolini. Danas je uobičajeno, uz informacije u tiskanom obliku, koristiti se različitim izvorima informacija u digitalnom obliku. Ključna uloga u objavljivanju rezultata znanstvenih i stručnih istraživanja i dalje pripada časopisima, bilo u tiskanom ili digitalnom obliku. ${ }^{4}$

Znanstveni časopis kao komunikacijski medij otvara mnoge mogućnosti za istraživanja. Od 1960-ih godina nadalje uočava se porast kvantitativnih istraživanja obilježja časopisa, odnosno radova/članaka koje oni objavljuju kao osnovnih jedinica na kojima se provode, tzv. bibliometrijske analize. Bibliometriju kao pojam uveo je Pritchard 1969. godine te je predložio da se tim izrazom zamijeni raniji neprikladan naziv „statistička bibliografija“ koji je uveo Hulme. ${ }^{5}$ Godine 1923. Pritchard je bibliometriju opisao kao niz matematičkih i statističkih metoda koje daju uvid u komunikaciju koja se odvija putem knjiga i drugih medija komunikacije ${ }^{6}$ te također može upućivati na smjerove razvoja pojedinog znanstvenog područja. Prema definiciji Organizacije za ekonomsku suradnju i razvoj (Organization for Economic Co-operation and Development, OECD), bibliome-

\footnotetext{
3 Vejmelka, L.; K. Švenda-Radeljak. Ljetopis socijalnog rada (1994.-2013.): dvadeset godina kontinuiranog izlaženja. // Ljetopis socijalnog rada 21, 2(2014), str. 314.

4 Zabajn Bogut, A.; T. Krajna. Trideset godina časopisa Polimeri: bibliometrijske značajke kategoriziranih radova. // Polimeri 32, 2(2011). Str. 81.

5 Eom, S. Author cocitation analysis: quantitative methods for mapping the intellectual structure of an academic discipline. Hershey; New York: Information Science Reference, 2008. Str. 3.

6 Tella, A.; A. O Issa. Library and information science in developing countries: contemporary issues. Hershey : Information Science Reference, 2012. Str. 304.
} 
trijske se analize temelje na podatcima o broju znanstvenih radova, njihovih citata i njihovih autora s ciljem mjerenja produkcije i odjeka pojedinaca / istraživačkih timova, ustanova i država, identificiranja nacionalnih i internacionalnih suradničkih mreža i otkrivanja novih polja znanosti i tehnologije. ${ }^{7}$ Bibliometrijskim istraživanjima hrvatskih časopisa bavili su se mnogi. Neka od istraživanja u prirodnim i tehničkim znanostima te biomedicini i zdravstvu jesu i sljedeća: Jokić i Borić $^{8}$ istražile su 1992. godine znanstvenu aktivnost na području botanike mjereno kroz časopis Acta Botanica Croatica. Godine 2004. Krajna i Petrak ${ }^{9}$ istražile su bibliometrijske karakteristike časopisa Strojarstvo. Borić i Strujić ${ }^{10}$ 2006. godine napravili su bibliometrijsku analizu časopisa Acta Stomatologica Croatica, a dvije godine kasnije Borić je napravila citatnu analizu istog časopisa u bazi podataka Web of Science. ${ }^{11}$ Takve analize u području društvenih i humanističkih znanosti u svijetu i Hrvatskoj bile su rjeđe. Mogući je razlog važnost knjiga kao komunikacijskog medija u većini polja i disciplina društvenih, a pogotovo humanističkih znanosti. Neka od istraživanja iz različitih polja društvenih znanosti jesu sljedeća: Dukić12 je 1990. godine provela citatnu analizu triju domaćih socioloških časopisa, Švenda-Radeljak provela je $2006 .{ }^{13}, 2010 .^{14}$ i 2014 . godine ${ }^{15}$ tri bibliometrijska istraživanja na dvama društvenim časopisima. Martek i Šute ${ }^{16}$ provele su 2010. godine bibliometrijsko istraživanje na časopisu Arhivski vjesnik, a Jokić i Zauder 2013. godine analizirali su časopis Sociologija sela. ${ }^{17}$ Iako je uloga časopisa u znanosti u osnovi ista, neovisno o području, oni se razlikuju po

7 Macan, B.; J. Petrak. Bibliometrijski pokazatelji za procjenu kvalitete znanstvenih časopisa. // Hrvatski znanstveni časopisi : iskustva, gledišta, mogućnosti. / Ur. Ivana Hebrang Grgić. Zagreb : Školska knjiga, 2015. Str. 40.

8 Jokić, M.; V. Borić. Znanstvena aktivnost na području botanike mjerena kroz časopis Acta Botanica Croatica. // Acta botanica Croatica 51, 1(1992), 169-176.

9 Krajna, T.; J. Petrak. Bibliometric characteristics of the journal Strojarstvo in the Period 19922001. // Strojarstvo: časopis za teoriju i praksu u strojarstvu 46, 1-3(2004), 19-23.

10 Borić, V.; M. Strujić. Bibliometric analysis of Acta stomatologica Croatica: 1987-2006.// Acta stomatologica Croatica 40, 4(2006), 345-355.

11 Borić, V. Analiza citata radova objavljenih u časopisu Acta zabilježenih u bazi podataka Web of Science. // Acta stomatologica Croatica 42, 2(2008), 123-139.

12 Dukić, Z. Mjesto sociologije u sistemu znanosti: citatna analiza triju domaćih socioloških časopisa. // Revija za sociologiju 21, 3(1990), 455-465.

13 Švenda Radeljak, K. Journal Social Work: the first decade (1960-1969). // Ljetopis socijalnog rada $13,1(2006), 115-132$.

14 Švenda-Radeljak, K. Revija za socijalnu politiku: petnaest godina kontinuiranog izlaženja (1994.-2008.). // Revija za socijalnu politiku 17, 1(2010), 155-170.

15 Vejmelka, L. ; K. Švenda-Radeljak. Nav. dj.

16 Martek, A. ; S. Šute. Bibliometrijska analiza časopisa Arhivski vjesnik u razdoblju od 2001. do 2009. // Arhivski vjesnik 53, 1(2010), 165-176.

17 Jokić, M.; K. Zauder. Bibliometrijska analiza časopisa Sociologija sela / Sociologija i prostor u razdoblju 1963.- 2012. // Sociologija i prostor 51, 2(2013), 331-349. 
svojim oblikovnim karakteristikama te načinima objavljivanja rezultata istraživanja i znanstvenih spoznaja, npr. vrstama članaka, strukturi članaka, vrstama i oblicima navođenja korištene literature i sl. Bibliometrijskom analizom može se upoznati struktura znanstvene aktivnosti unutar neke znanstvene discipline, zemlje ili regije. Može se saznati o širini utjecaja pojedine znanstvene publikacije, stupnju znanstvene produktivnosti te stupnju međunarodne suradnje.

Svrha i cilj ovog istraživanja jest to da na osnovi određenih bibliometrijskih pokazatelja dobijemo uvid u razvoj ovog časopisa tijekom dvadesetjednogodišnjeg izlaženja te utjecaj časopisa na znanstvenu zajednicu.

\section{Istraživanje}

\subsection{Pristup istraživanju i metode}

U ovome radu naglasak je na analizi određenih bibliometrijskih pokazatelja časopisa Medijska istraživanja u dvadesetjednogodišnjem razdoblju (od 1995. do 2015. godine). Provedena je citatna analiza časopisa na temelju podataka o citiranosti dostupnih na portalu Web of Science (WoS) kao nezaobilaznog izvora kada je riječ o bibliometrijskim analizama časopisa te Scopusa, citatne i bibliografske baze podataka koja se pojavila 2004. godine. Članci su promatrani i analizirani prema određenim parametrima: broj članaka po godinama, kategorizacija članaka, broj autora i ustanova, jezik publiciranja, citatne reference te vidljivost časopisa u sekundarnim izvorima.

\subsection{Rezultati i rasprava}

Korištenjem bibliometrijskih metoda analizirani su svi članci objavljeni u časopisu Medijska istraživanja tijekom dvadesetjednogodišnjeg razdoblja. Svi članci (ukupno 276 kategoriziranih radova te 227 priloga $^{18}$ ) pregledani su de visu, od 1995. do 2015. Izvršena je kategorizacija članaka na znanstvene članke i druge priloge. Radovi su zatim kategorizirani prema vrstama. Kako bi se lakše mogli pratiti trendovi razvoja časopisa kroz vrste radova, radovi su kategorizirani prema UNESCO-ovim preporukama u znanstvenim i stručnim publikacijama: izvorni znanstveni rad, prethodno priopćenje, pregledni rad i stručni rad. ${ }^{19}$ Osim toga, u znanstvenim se časopisima tiskaju i izlaganja sa skupova te prikazi knjiga i skupova, obavijesti o programima i projektima i sl. Kategorizacija je preuzeta u obliku koji je odredilo uredništvo časopisa u suradnji s recenzentima u trenutku objavljivanja radova.

18 U kategoriju prilozi svrstane su recenzije, prikazi, bilješke, prijevodi, intervjui i uvodnici.

19 Zgrabljić Rotar, N. Medijska istraživanja i medijska disciplina od 1995. do 2005. Zagreb: Doron, 2005. Str. 20. 
U svrhu boljeg pregleda uloge i znanstvenog utjecaja samog časopisa analizirani su i podatci o autorima. Analiziran je broj autora pojedinih kategoriziranih radova te institucije iz kojih autori dolaze. Svi su ti podatci prikazani prema svojim karakteristikama ukupno i/ili po godištima te su tabelarno uređeni i/ili verbalno opisani.

\subsubsection{Dinamika izlaženja}

U analiziranom dvadesetjednogodišnjem razdoblju objavljeno je 37 sveščića. Ukupno je objavljeno 276 kategoriziranih radova. Tijekom dvadeset godina izlazila su po 2 sveščića godišnje, osim 1997., 2001. i 2011. godine, kada je izašao po 1. sveščić (dvobroj). Tijekom svih proteklih godina časopis je izlazio redovito i kontinuirano.

\subsubsection{Uredništvo}

Tijekom dvadeset jedne godine izlaženja mijenjala se donekle struktura uredništva. Prvo uredništvo časopisa od sedam članova, na inicijativu glavne urednice, činili su profesori s različitih fakulteta Sveučilišta u Zagrebu i Ljubljani. Svima je bilo zajedničko to što su tijekom karijere istraživali medije u sklopu svojih znanstvenih disciplina te su o tome pisali i objavljivali radove. Glavna je urednica časopisa Nada Zgrabljić Rotar. Prvo uredništvo činili su Vladimir Biti, Ivan Ivas, Tomo Jantol, Manca Košir, Zrinjka Peruško, Nenad Prelog i Ivo Škarić, a 2004. godine pridružila im se Smiljana Novosel Leinert. Tijekom dvadesetjednogodišnjeg razdoblja mijenjao se i sastav članova uredništva te od 2014. godine uredništvo čine Ivan Burić, Maja Jokić, Jelena Jurišić, Danijel Labaš, Marko Milosavljevič, Tena Perišin, Melita Poler-Kovačić i Igor Vobič.

\subsubsection{Kategorizacija članaka}

Analizom je izvršena kategorizacija na znanstvene radove i druge priloge. Članci su zatim kategorizirani prema vrstama: izvorni znanstven rad, prethodno priopćenje, pregledni rad, stručni rad i izlaganja sa skupova (uvršteni su i preneseni i prevedeni $\operatorname{rad}^{20}$ zato što im je kategorizacija jasno označena uz članak). U kategoriju prilozi svrstane su recenzije, prikazi, bilješke, prijevodi, intervjui i uvodnici. U malim i novim znanstvenim područjima, znanstveni radovi sudjeluju u izgradnji epistemologije i znanstvenog jezika. Osim toga, omjer stručnih i znanstvenih radova upućuje na širu zajednicu koja je zainteresirana za određeno znanstveno područje. Slika 1. prikazuje kretanje broja objavljenih kategoriziranih radova i priloga po pojedinim godinama u razdoblju od 1995. do 2015. godine.

20 Radovi koji su preneseni ili prevedeni iz stranih časopisa, a koje je uredništvo Medijskih istraživanja iz nekog razloga smatralo vrijednima ili važnima za čitatelje i medijske proučavatelje u Hrvatskoj. 


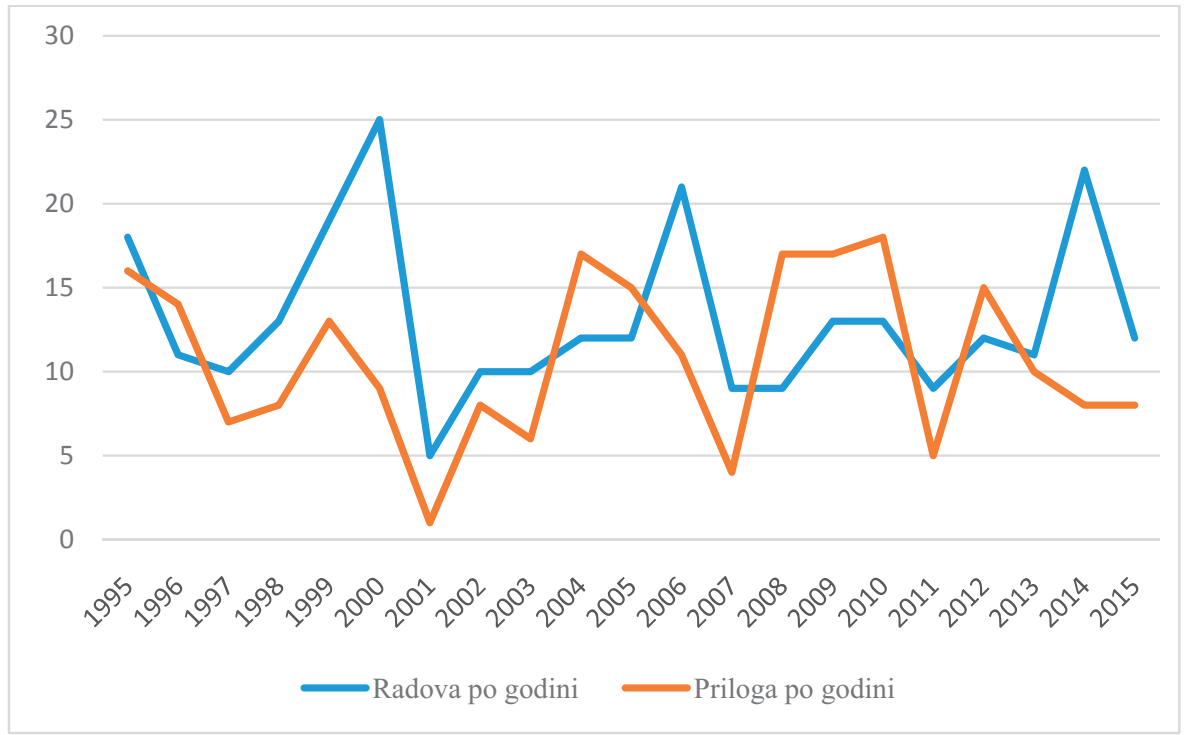

Slika 1. Članci objavljeni u Medijskim istraživanjima od 1995. do 2015. g.

Što se tiče kretanja kategoriziranih radova po pojedinim godinama u razdoblju od 1995. do 2015. godine, najviše ih je objavljeno 2000. (25), 2006. (21) i 2014. godine (22). Prosječno je po broju objavljeno 7,5 kategoriziranih radova, a od toga prosječno 3,4 izvorna znanstvena rada.

Sveukupno je u dvadesetjednogodišnjem razdoblju objavljeno 276 kategoriziranih radova, i to: 127 izvornih znanstvenih radova (46 \%), 51 stručni rad (18,5 $\%), 41$ pregledni rad (14,9\%), 34 izlaganja sa skupa (12,3\%), 17 prethodnih priopćenja $(6,2 \%), 3$ prenesena rada $(1,1 \%)$ te 3 prevedena rada $(1,1 \%)$. Jedan je od pokazatelja razvoja određenog znanstvenog područja i broj izvornih i ostalih znanstvenih radova. Ukupan udio izvornih znanstvenih radova iznosi visokih 127 (46\%), što svakako ukazuje na znanstvenu odliku časopisa. Analizirajući udio izvornih i preglednih radova (sveukupno $61 \%$ ) unutar skupine članaka, može se zaključiti da je ispunjeno jedno od obilježja znanstvenog časopisa prema prvim i osnovnim kriterijima, a to je da rukopisi koji se prihvaćaju za objavljivanje trebaju sadržavati nove znanstvene informacije.

Osim kategoriziranih radova, časopis objavljuje i stalnu rubriku Recenzije, prikazi, bilješke, gdje se objavljuju prikazi i recenzije novih i relevantnih knjiga vezanih uz multidisciplinarno područje medija i novinarstva, bilješke s domaćih i inozemnih stručnih i znanstvenih skupova te razne novosti i informacije. U kategoriju prilozi svrstane su recenzije, prikazi, bilješke, prijevodi, intervjui i uvodnici. Ukupno je u promatranom dvadesetjednogodišnjem razdoblju objavljeno 227 
priloga, i to prosječno 6,13 godišnje. Najviše ostalih priloga objavljeno je 2010. $(7,9 \%)$ te 2004., 2008. i 2009. godine (7,5\%).

Većina radova objavljena je na hrvatskom jeziku (60,5\%), dok je 38,7 \% kategoriziranih radova objavljeno na engleskom jeziku. Kategorizirani radovi napisani na hrvatskom jeziku imaju naslov rada, ključne riječi, naslove slika i tablica objavljene usporedno i na engleskom jeziku.

$\mathrm{Na}$ temelju navedenih podataka, sustavne formalne kategorizacije radova, visokog udjela znanstvenih radova, što uključuje i pregledne radove i prethodna priopćenja, kao i dobre zastupljenosti radova na engleskom jeziku, može se zaključiti da časopis Medijska istraživanja prema formalno-oblikovnim karakteristikama ima odlike znanstvenog časopisa.

\subsubsection{O autorima kategoriziranih radova}

Proučavanjem autorstva proučava se možda najvažnija veza između aktera u znanosti i izlaza znanstvenih procesa. Proučavanje autorstva i autora možemo u načelu podijeliti na proučavanje radova u odnosu na broj autora, proučavanje autora u odnosu na radove te proučavanje suradnje. ${ }^{21}$ Podatci o autorima analizirani su prema najproduktivnijim autorima, broju autora u pojedinim radovima prema godinama izlaženja, kategorizaciji rada te ustanovama iz koje dolaze.

Analizirajući autorstvo u odnosu na broj radova koje su objavili pojedini autori, dolazi se do podataka da je po jedan rad u dvadesetogodišnjem razdoblju objavilo 214 autora $(82,6 \%)$, po dva rada 27 autora $(10,4 \%)$, po tri rada 27 autora $(3,1$ $\%$ ), po četiri rada 3 autora (1,2\%), a po pet radova 3 autora (1,2\%). Najproduktivniji autori bili su Volčić Zala (6 radova), Nada Zgrabljić Rotar (11 radova) te Karmen Erjavec i Melita Poler Kovačić (12 radova). Iako se za kvalitetu časopisa u dvadesetjednogodišnjem razdoblju najviše zasluga može pripisati urednicima i njihovoj uređivačkoj politici, na određen način iznenadio je podatak da su među najproduktivnijim autorima glavna urednica i članica uredništva. Taj je podatak indikativan, i to s više aspekata. Prema definiciji znanstvenog časopisa, urednici časopisa ne bi trebali biti česti autori radova u tim časopisima, no takva pojava može se tumačiti i drukčije. Melita Poler Kovačić dvanaest je radova objavila prije nego što je postala članica uredništva (od 2014. godine). Glavna urednica Nada Zgrabljić-Rotar jedanaest je radova objavila u razdoblju od dvadeset jedne godine. Što se tiče kategorizacije radova koji su objavljeni u časopisu, 4 su kategorizirana kao izvorni znanstveni radovi, 3 kao pregledni radovi, 3 kao stručni radovi, a jedan kao prethodno priopćenje. Ti podatci mogu upućivati na stručnost autora u temama kojima se bave Medijska istraživanja te se ne moraju tumačiti negativno. U obzir se može uzeti i manjak autora koji se bave određenom temati-

${ }^{21}$ Zauder, K. Razvoj sciontometrije praćen kroz časopis Scientometrics od početka izlaženja 1978. do 2010. godine:doktorski rad. Zagreb : Filozofski fakultet Sveučilišta, 2014. Str. 86. 
kom, jer časopis djeluje u malenoj hrvatskoj zajednici, što može biti razlog većoj eksponiranosti određenih autora. ${ }^{22}$

Pojam suradnje među znanstvenicima odnosi se na zajednički rad istraživača u svrhu postizanja zajedničkog cilja, a to je otkrivanje novih spoznaja i stjecanje znanja. ${ }^{23}$ Proučavanje radova $u$ odnosu na autore prvenstveno daje informaciju o broju autora rada. Opis distribucije broja autora po radu pruža važan uvid u trendove pisanja i suradnje u nekom području. U posljednjih nekoliko desetljeća dolazi do povećanja znanstvene suradnje, što se očituje u sve većem apsolutnom i relativnom broju višeautorskih radova u odnosu na jednoautorske radove. Autorstvo postaje kolektivna aktivnost s velikim brojem suautora. U nekim područjima, kao što su kemija i biomedicina, gotovo da i ne postoje jednoautorski radovi. Napredak u informacijskoj i komunikacijskoj tehnologiji umanjuje prepreke u suradnji zbog geografske udaljenosti te dovodi do suradnje među autorima. Osim toga, do suradnje dolazi i zbog sve većeg pritiska znanstvenika koji se prijavljuju za dobivanje sredstava za istraživanje, potrebe za objavljivanjem što većeg broja radova, veće vjerojatnosti prihvaćanja rada za objavljivanje, poticaja od strane znanstvene politike, specijalizacije zbog rasta znanja, potrebe za multidisciplinarnim pristupom, potrebe za specifičnim tehnološko-analitičkim vještinama ${ }^{24}$, sinergije - na način da više ljudi zajednički dolazi do ideje do koje nitko od njih ne bi došao samostalno - te suradnje između studenata i profesora u kojoj dolazi do ostvarivanja obostrane dobrobiti u vidu ideja i novih pristupa. ${ }^{25}$.

Analizirane kategorizirane radove potpisuje 358 autora. Više od polovine čine jednoautorski radovi (59,7 \%). Radova u suautorstvu dvaju autora ukupno je $25,7 \%$, dok je u suautorstvu triju autora napisano $10,9 \%$ radova. Prosječno, broj autora po radu jest 1,3 (tablica 1). Analizirajući autorstvo u odnosu na godine, primjećuje se da broj višestrukih autorstava raste, pogotovo kada su u pitanju suautorstva dvoje autora. Godine 2007. objavljen je jedan rad s pet autora, što je, sveukupno gledajući, maksimalan broj autora. Za usporedbu navodimo neka od srodnih istraživanja. Endersby je na uzorku radova znanstvenika u trinaest časopisa iz područja društvenih znanosti u razdoblju od 1984. do 1994. godine dobio podatak da je većina radova objavljena u suautorstvu, i to: političke znanosti više od $46 \%$, psihologija više od $79 \%$, a sociologija više od $50 \%{ }^{26}$ Feinberg, Watnick i Sacks, na uzorku od 7352 rada znanstvenika u devetnaest znanstvenih časopisa

22 Jokić, M. ; K. Zauder. Nav.dj., str. 337.

23 Jokić, M. Bibliometrijski aspekti vrednovanja znanstvenog rada. Zagreb : Sveučilišna knjižara, 2005.

24 Iglič, H.; P. Doreian ; L. Kronegger; A. Ferligoj. With whom do researchers collaborate and why? // Scientometrics 112(2017), str. 154.

25 Endersby, J.W. Collaborative research in the social sciences: multiple autorship and publication credit. // Social Science Quarterly 77, 2(1996), str. 376.

26 Endersby, J.W. Nav. dj., str. 380. 
iz društvenih znanosti u razdoblju od 1996. do 2006. godine, dobili su podatak da je većina radova objavljena u suautorstvu, i to: političke znanosti više od $40 \%$, psihologija više od $73 \%$, a sociologija više od $57 \%{ }^{27}$ Jokić, Zauder i Letina proveli su istraživanje o autorstvu na radovima hrvatskih znanstvenika objavljenim u hrvatskim časopisima u razdoblju od 1991. do 2005. godine te su utvrdili da je u društvenim znanostima bilo 71,4 \% jednoautorskih radova. Analiza autorstva na radovima znanstvenika iz polja informacijskih znanosti pokazuje nešto drukčiju sliku u odnosu na uzorak za društvene znanosti kao cjelinu. Iako je broj jednoautorskih radova najzastupljeniji kao i kod društvenih znanosti, njihov je postotak različit. Udio jednoautorskih radova za ovo znanstveno polje bio je $54,4 \%$. Isto tako, radovi s više autora (2-5) druga su najzastupljenija skupina, ali je postotak znatno viši u odnosu na društvene znanosti kao cjelinu i iznosi $44,2 \%{ }^{28}$

Tablica 1. Broj autora u pojedinom radu prema godinama objavljivanja

\begin{tabular}{|l|c|c|c|c|c|c|}
\hline \multirow{2}{*}{ Godina } & \multicolumn{7}{|c|}{ Broj autora po radu } & \multirow{2}{*}{$\begin{array}{c}\text { Ukupno } \\
\text { autora }\end{array}$} \\
\cline { 2 - 7 } & $\mathbf{1}$ & $\mathbf{2}$ & $\mathbf{3}$ & $\mathbf{4}$ & $\mathbf{5}$ & 18 \\
\hline 1995. & 18 & 0 & 0 & 0 & 0 & 11 \\
\hline 1996. & 11 & 0 & 0 & 0 & 0 & 10 \\
\hline 1997. & 10 & 0 & 0 & 0 & 0 & 15 \\
\hline 1998. & 11 & 2 & 0 & 0 & 0 & 23 \\
\hline 1999. & 16 & 2 & 1 & 0 & 0 & 27 \\
\hline 2000. & 23 & 2 & 0 & 0 & 0 & 5 \\
\hline 2001. & 5 & 0 & 0 & 0 & 0 & 12 \\
\hline 2002. & 9 & 0 & 1 & 0 & 0 & 12 \\
\hline 2003. & 8 & 2 & 0 & 0 & 0 & 18 \\
\hline 2004. & 8 & 2 & 2 & 0 & 0 & 13 \\
\hline 2005. & 11 & 1 & 0 & 0 & 0 & 24 \\
\hline 2006. & 18 & 3 & 0 & 0 & 0 & 16 \\
\hline 2007. & 6 & 1 & 1 & 0 & 1 & 9 \\
\hline 2008. & 9 & 0 & 0 & 0 & 0 & \\
\hline
\end{tabular}

27 Feinberg, G. ; B. Watnick ; A. Sacks. Solo vs. Collaborative research in the social sciences and higher education: unraveling the realities of male-female research publication patterns in the context of gender politics and social justice issues. // Journal of Multidisciplinary Research 3, 3(2011), 47-63.

28 Jokić, M. ; K. Zauder ; S. Letina. Karakteristike hrvatske nacionalne i međunarodne znanstvene produkcije u društveno-humanističkim znanostima i umjetničkom području za razdoblje 1991-2005. Zagreb: Institut za društvena istraživanja, 2012. 


\begin{tabular}{|l|c|c|c|c|c|c|}
\hline \multirow{2}{*}{ Godina } & \multicolumn{7}{|c|}{ Broj autora po radu } & \multirow{2}{*}{$\begin{array}{c}\text { Ukupno } \\
\text { autora }\end{array}$} \\
\cline { 2 - 6 } & $\mathbf{1}$ & $\mathbf{2}$ & $\mathbf{3}$ & $\mathbf{4}$ & $\mathbf{5}$ & 16 \\
\hline 2009. & 10 & 3 & 0 & 0 & 0 & 18 \\
\hline 2010. & 9 & 3 & 1 & 0 & 0 & 13 \\
\hline 2011. & 5 & 4 & 0 & 0 & 0 & 21 \\
\hline 2012. & 6 & 4 & 1 & 1 & 0 & 19 \\
\hline 2013. & 5 & 5 & 0 & 1 & 0 & 38 \\
\hline 2014. & 10 & 8 & 4 & 0 & 0 & 20 \\
\hline 2015. & 6 & 4 & 2 & 0 & 0 & 358 \\
\hline $\begin{array}{l}\text { Ukupno } \\
\text { Total }\end{array}$ & $\mathbf{2 1 4}$ & $\mathbf{9 2}$ & $\mathbf{3 9}$ & $\mathbf{8}$ & $\mathbf{5}$ & $\mathbf{1 0 0}$ \\
\hline Udio \% & $\mathbf{5 9 , 7 7}$ & $\mathbf{2 5 , 6 9}$ & $\mathbf{1 0 , 8 9}$ & $\mathbf{2 , 2 3}$ & $\mathbf{1 , 3 9}$ & \\
\hline
\end{tabular}

Ukoliko se promatraju države iz kojih dolaze pojedini autori, dobiveni su podatci da autori kategoriziranih radova dolaze iz 25 država. Za potrebe analize radova prema zemlji iz koje dolaze autori, radovi su podijeljeni u tri grupe: hrvatski autori, autori iz regije (zemlje bivše Jugoslavije bez Hrvatske) te autori iz ostalih zemalja. Promatrajući jednoautorske radove prema zemlji iz koje dolaze autori (tablica 2), pokazuje se da je većina autora iz Hrvatske (53\%), a zatim slijede radovi autora iz regije (od 58 radova, 52 su rada autora iz Slovenije) te autori iz ostalih zemalja (19,3\%). Ako analiziramo radove višestrukog autorstva, većina je radova hrvatskih suautora $(68,3 \%)$, a zatim slijede radovi suautora iz regije $(20,6 \%)$. Što se tiče same suradnje među autorima, ona je orijentirana prema zemljama iz koje dolaze sami autori, međunarodna suradnja postoji u samo 4 rada, $i$ to u jednom radu suradnja autora iz Hrvatske i Slovenije, u jednom iz Slovenije i Nizozemske, u jednom iz Slovenije i Švedske, a u jednom iz SAD-a i Slovačke. Dobiveni podatci ukazuju na nacionalnu i regionalnu orijentaciju časopisa.

Tablica 2. Broj jednoautorskih i višeautorskih radova prema zemlji iz koje dolaze autori

\begin{tabular}{|l|c|c|c|c|}
\hline & $\begin{array}{c}\text { Hrvatski } \\
\text { autori }\end{array}$ & $\begin{array}{c}\text { Autori } \\
\text { iz regije }\end{array}$ & $\begin{array}{c}\text { Autori iz } \\
\text { ostalih zemalja }\end{array}$ & Ukupno \\
\hline Jednoautorski radovi & 113 & 59 & 41 & 213 \\
\hline$\%$ & 53 & 27,7 & 19,3 & 100 \\
\hline Višeautorski radovi & 43 & 13 & 7 & 63 \\
\hline$\%$ & 68,3 & 20,6 & 11,1 & 100 \\
\hline
\end{tabular}


Analizom ustanova iz kojih dolaze autori, očekivano, utvrđuje se da je najveći broj autora iz raznih domaćih i stranih sveučilišta te znanstvenih instituta. Sveukupno, autori dolaze iz 109 različitih ustanova. U skupini ustanova čiji su znanstvenici objavili više od tri članka nalazi ih se 20 (tablica 3), s ukupnim udjelom od $48,7 \%$ radova.

Tablica 3. Ustanove s tri ili više objavljenih radova

\begin{tabular}{|l|c|}
\hline \multicolumn{1}{|c|}{ Naziv ustanove } & Učestalost \\
\hline Fakultet društvenih znanosti Sveučilišta u Ljubljani (SI) & 57 \\
\hline Filozofski fakultet, Zagreb (HR) & 31 \\
\hline Fakultet političkih znanosti, Zagreb (HR) & 25 \\
\hline Filozofski fakultet, Zadar (HR) & 9 \\
\hline Fakultet organizacije i informatike u Varaždinu (HR) & 8 \\
\hline Filozofski fakultet, Osijek (HR) & 6 \\
\hline Hrvatski studiji, Zagreb (HR) & 6 \\
\hline Institut za društvena istraživanja u Zagrebu (HR) & 5 \\
\hline Medicinski fakultet, Zagreb (HR) & 5 \\
\hline Nacionalna i sveučilišna knjižnica u Zagrebu (HR) & 5 \\
\hline Filozofski fakultet, Split (HR) & 4 \\
\hline Hrvatska akademska i istraživačka mreža - CARNet (HR) & 4 \\
\hline University Amsterdam, Faculty of Social Sciences (NL) & 4 \\
\hline Hrvatsko novinarsko društvo (HR) & 3 \\
\hline Institut za međunarodne odnose (HR) & 3 \\
\hline OTP banka d.d., Zadar (HR) & 3 \\
\hline Pravni fakultet, Zagreb (HR) & 3 \\
\hline Studij za obrazovanje socijalnih radnika (HR) & 3 \\
\hline University of Colorado at Boulder (SAD) & 3 \\
\hline Veleučilište VERN (HR) & 3 \\
\hline
\end{tabular}

Analizirajući autorstvo prema domaćim i stranim autorima utvrđuje se da je $59,7 \%$ domaćih te $40,2 \%$ stranih autora. Distribucija domaćih i stranih autora po godinama (slika 2) pokazuje da su 2005., 2009., 2011. i 2013. godine strani autori objavili veći broj radova nego domaći, a 1999., 2006., 2010., 2012. i 2015. godine domaći su autori objavili veći broj radova nego strani. 


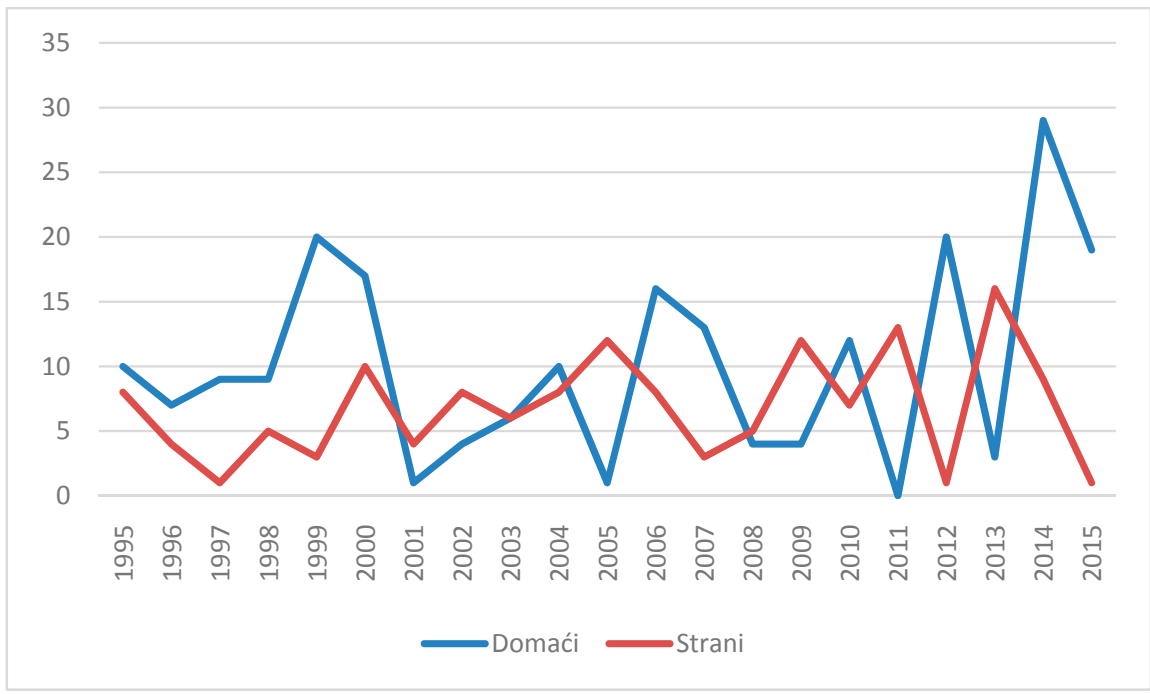

Slika 2. Strani i domaći autori prema godinama izlaženja

\subsubsection{Vidljivost časopisa}

Zastupljenost (indeksiranost) časopisa u relevantnim sekundarnim izvorima informacija od velike je važnosti za vrednovanje znanstvenog rada, kao i za vidljivost znanstveno-stručnih časopisa u međunarodnoj znanstvenoj zajednici. Postoji čitav niz različitih relevantnih sekundarnih disciplinarnih i multidisciplinarnih baza podataka, ali se međunarodna prepoznatljivost znanstvenih i stručnih časopisa najčešće mjeri na temelju zastupljenosti u bibliografskim i citatnim bazama podataka kolekcije Web of Science Core Colection (Clarivate Analytics) i Scopus (Elsevier). Na temelju indeksiranih radova u citatnim bazama podataka WoSCC i Scopus provodi se većina bibliometrijskih istraživanja.

Najpoznatiji bibliometrijski pokazatelj o časopisima, tzv. čimbenik odjeka (engl. impact factor - IF), Clarivate Analytics objavljuje u svom drugom proizvodu, statističkoj bazi podataka Journal Citation Reports na platformi InCites (od 2016.).

$\mathrm{Na}$ temelju podataka o citiranosti radova iz Scopusa izračunavaju se dva nova bibliometrijska pokazatelja: SCImago Journal Rank (SJR) koji je dostupan besplatno na portalu SCImago Journal \& Country Rank te Source Normalized Impact per Paper (SNIP) koji se objavljuje na stranicama http://www.journalindicators. com/ CWTS Journal Indicators. Oba pokazatelja dostupna su i u sklopu Scopusa, u dijelu u kojem je omogućeno pregledavanje časopisa (Browse Sources).$^{29}$ Citat-

29 Macan, B.; Jelka P. Nav. dj. Str. 40. 
ne baze podataka neprekidno se mijenjaju i razvijaju, uključuju se novi časopisi te isključuju stari (indeksirani časopisi koji ne zadovoljavaju kriterije kvalitete časopisa koje propisuju citatni indeksi), unapređuju se mogućnosti pretraživanja i uvode novi bibliometrijski pokazatelji (npr. krajem 2015. u svoje citatne analize Thomson Reuters, kasnije Clarivate Analytics, uveo je altmetrijske pokazatelje Usage Count). Objavljene analize uvijek se odnose samo na vrijeme u kojem je specifično istraživanje provedeno, što je potrebno napomenuti. Vidljivost časopisa Medijska istraživanja postignuta je zastupljenošću u značajnim sekundarnim disciplinarnim bazama podataka Library, Information Science \& Technology Abstracts (LISTA), Sociological Abstracts (SA), Linguistic and Language Behavior Abstracts (LLBA), a pogotovo od 2011. godine, kada je indeksiran u multidisciplinarnoj bibliografskoj i citanoj bazi podataka Scopus. Svoju vidljivost povećao je osiguravanjem pristupa cjelovitim tekstovima objavljenih radova dostupnih preko Portala znanstvenih časopisa Republike Hrvatske - Hrčak (http://hrcak.srce.hr/?lang=hr) od vol. 6 (2000), br. 1. U Hrčak je uključen 2. studenoga 2007. godine.

\subsubsection{Analiza citiranosti}

Procjena kvalitete nekog znanstvenog rada, znanstvenika, grupe znanstvenika, časopisa ili znanstvenih institucija, pa i država, danas se često provodi na temelju broja citata koje su dobili radovi pojedinih znanstvenika. Citiranost radova objavljenih u časopisu Medijska istraživanja može se provjeriti u bibliografskoj i citatnoj bazi podataka Scopus te u kolekciji citatnih indeksa WoSCC. Citatnu analizu časopisa moguće je provesti po WoSCC-u iako časopis nije indeksiran u WoSCC-u, pretražujući prema naslovu časopisa pomoću Cited Reference Search (WoSCC from All databases). Pretraživanje citata u WoSCC-u koje su dobili radovi objavljeni u Medijskim istraživanjima od trenutka kada je časopis počeo izlaziti provedeno je u srpnju 2016., a pretraživanje časopisa provodilo se po različitim inačicama naslova časopisa (Medijska istrazivanj, Medijska istrazivanja, Medij istraz, Med istrazivanja, Med istrazanja, Medijska istragivanja, Medijska istraivanja te u engleskoj inačici naziva časopisa Media res i Media research). Jedan citirani rad odnosio se na rad iz zbornika radova Medijska istraživanja (Novi Sad), koji se ne odnosi na časopis Medijska istraživanja. Pojedine citirane reference ponavljaju se pretraživanjem po različitim inačicama navoda časopisa. Također, kod pojedinih referenci pogrešno su uneseni podatci o volumenu ili broju, kod nekih su krivo uneseni brojevi stranica, imena autora istog rada često nisu navedena ujednačeno. Sve navedeno dovodi do toga da svi citati jednog rada mogu biti pridruženi uz nekoliko različito navedenih jedinica, pa su kod analize dupli navodi izostavljeni, a krivo pridruženi citati jednog rada pravilno okupljeni. Nakon pravilnog okupljanja citata i izostavljanja onih dvostrukih, ukupan broj različitih citiranih referenci iznosi 52 reference, koje su ukupno dobile 89 citata (tablica 4 ). 
Tablica 4. Broj citata po radu

\begin{tabular}{|c|c|c|c|c|}
\hline \multicolumn{4}{|c|}{ Broj citata po radu } & \multirow[b]{2}{*}{ Ukupno radove } \\
\hline 1 & 2 & 3 & 4 & \\
\hline \multirow[t]{2}{*}{31} & 12 & 2 & 7 & 52 \\
\hline & & & & Ukupno citata \\
\hline 31 & 24 & 6 & 28 & 89 \\
\hline $34,8 \%$ & $28,6 \%$ & $6,7 \%$ & $31,5 \%$ & $100,00 \%$ \\
\hline
\end{tabular}

Prema broju citata koje su dobili najcitiraniji radovi može se izračunati $h$-indeks. H-indeks je relativno nov indikator koji je E. Hirsch u svom radu iz 2005. godine opisao kao pokazatelj znanstvenog odjeka istraživača. ${ }^{30} \mathrm{H}$-indeks nastoji objediniti kvantitativni doprinos znanstvene djelatnosti prikazan brojem objavljenih radova i kvalitativni odjek prikazan brojem citata koji je dobio određeni objavljeni rad. Taj indikator može se koristiti kao mjera kvalitete rada znanstvenika, kao i grupe znanstvenika, instituta, sveučilišta, zemlje, ali i časopisa. $H$-indeks nalazi se u bazi podataka WoSCC u sklopu podataka o citiranosti (Citation Report), koja nudi statističke podatke o broju publiciranih radova indeksiranih u citatnim indeksima WoSCC-a te o broju dobivenih citata. S obzirom na to da časopis Medijska istraživanja nije indeksiran u Social Science Citation Indexu, citatnom indeksu iz kolekcije WoSCC za područje društvenih znanosti, njegova je citiranost provjerena te mu je izračunat $h$-indeks putem opcije Cited Reference Search koja daje podatak o citiranosti i onih radova koji nisu indeksirani u WoS-ovim bazama, a citirali su ih autori koji su svoje radove objavili u časopisima koji su zastupljeni u Clarivate Analyticsovim citatnim indeksima. $\mathrm{H}$-indeks časopisa Medijska istraživanja izračunat putem opcije Cited Reference Search iznosi 4 , što znači da su četiri rada citirana najmanje četiri puta. Svi ostali radovi citirani su 3 i manje puta.

Opcija Cited Reference Search omogućuje i provjeru toga tko je citirao određeni rad. Provedena je analiza citiranosti svake pojedine jedinice te je utvrđeno da na ukupno 89 citata otpada 25,8\% samocitata (tablica 5). Smatra se da je postotak samocitata od 15 do $25 \%$ prihvatljiv. ${ }^{31} \mathrm{U}$ provedenoj analizi promatrana je samocitiranost koja se odnosi na autore koji su citirali vlastite radove, bez obzira na to kada su i gdje objavljeni. Podatak o samocitiranosti autora, kao i samocitiranosti

${ }^{30}$ Hirsch, J.E. An index to quantify an individual's scientic research output. // Proc Natl Acad Sci USA102, 46(2005), 16569-16572. [citirano:2016-07-19]. Dostupno na: http://www.pnas.org/ content/102/46/16569.full.pdf.

${ }^{31}$ Brajenović-Milić, B. Bibliometrijski pokazatelji znanstvenog odjeka autora i časopisa. // Medicina Fluminensis 50, 4(2014), str. 429. 
unutar časopisa, tj. citiranju prethodnih radova koje je objavio taj isti časopis, ali i podatak o autorima koji citiraju radove iz određenog časopisa, bitan je parametar kod promatranja časopisa za eventualni ulazak u Clarivate Analyticsove citatne indekse te o njemu ovisi i ulazak, kao i opstanak u pripadajućoj bazi podataka. Nije svejedno jesu li autori koji citiraju radove iz nekog časopisa urednici ili članovi uredništva, jesu li u većini autori koji objavljuju radove u tom časopisu ili se radi o sasvim nepoznatim autorima. Neovisni citati autora jesu citati koje autor dobiva od njemu nepoznatih autora izvan svoje institucije, a u slučaju malih zemalja i izvan svoje zemlje. ${ }^{32}$ Neovisni citati časopisa odnose se na članke iz drugih časopisa. ${ }^{33}$

Tablica 5. Vrsta citata

\begin{tabular}{|c|c|c|}
\hline \multicolumn{3}{|c|}{ Broj citata } \\
\hline Ukupno & Neovisni & Samocitati \\
\hline 89 & 66 & 23 \\
\hline $\mathbf{1 0 0} \%$ & $\mathbf{7 4 , 2} \%$ & $\mathbf{2 5 , 8} \%$ \\
\hline
\end{tabular}

Analizom publikacija, tj. članaka koji su citirali radove iz časopisa Medijska istraživanja putem opcije Cited Reference Search, utvrđeno je da su 52 rada časopisa Medijska istraživanja navedena u 68 radova, i to u 27 radova iz 12 hrvatskih časopisa i zbornika radova s različitih skupova te u 41 radu iz 26 stranih časopisa i zbornika (tablica 6).

Tablica 6. Broj publikacija i radova indeksiranih u WoSCC-u koji citiraju radove iz Medijskih istraživanja prema porijeklu izdavača časopisa

\begin{tabular}{|l|c|c|}
\hline \multicolumn{1}{|c|}{ Zemlja izdavača } & Broj publikacija & Broj radova \\
\hline Hrvatska & 12 & 27 \\
\hline Engleska & 15 & 22 \\
\hline Slovenija & 3 & 10 \\
\hline SAD & 5 & 6 \\
\hline Njemačka & 2 & 2 \\
\hline Nizozemska & 1 & 1 \\
\hline Ukupno & $\mathbf{3 8}$ & $\mathbf{6 8}$ \\
\hline
\end{tabular}

32 Jokić, M.. H-indeks kao novi scientometrijski indikator. // Biochemia Medica 19,1(2009), str. 7.

33 Macan, B.; Jelka P. Nav. dj., str. 45. 
U tablici 7 i tablici 8 navedene su hrvatske i strane publikacije koje su citirale radove Medijskih istraživanja te podatak o tome u koliko su radova iz svakog pojedinog časopisa ili zbornika citirani radovi iz istraživanog časopisa. Analizom citiranih referenci iz pojedinih publikacija utvrđeno je da su u 27 radova iz hrvatskih publikacija citirane 32 reference iz časopisa Medijska istraživanja. Najviše je citiranih referenci u časopisu Društvena istraživanja (11) te u časopisu Croatian Journal of Education (5 referenci). U ostalim hrvatskim časopisima Medijska istraživanja dobila su 3 i manje citata.

Tablica 7. Reference časopisa Medijska istraživanja u hrvatskim publikacijama.

\begin{tabular}{|l|c|c|}
\hline \multicolumn{1}{|c|}{ Naziv publikacije } & Broj radova & Broj citata \\
\hline Društvena istraživanja & 6 & 11 \\
\hline Croatian Journal of Education & 5 & 5 \\
\hline $\begin{array}{l}\text { Međunarodni znanstveni simpozij } \\
\text { Gospodarstvo istočne Hrvatske }\end{array}$ & 3 & 3 \\
\hline Filozofska istraživanja & 2 & 3 \\
\hline ITI Proceedings & 2 & 2 \\
\hline Književna smotra & 2 & 1 \\
\hline Ljetopis socijalnog rada & 2 & 2 \\
\hline Hrvatski filmski ljetopis & 1 & 1 \\
\hline Ekonomska istraživanja & 1 & 1 \\
\hline Ekonomski vjesnik & 1 & 1 \\
\hline Revija za socijalnu politiku & 1 & 1 \\
\hline Tehnički vjesnik & 1 & 1 \\
\hline Ukupno & 27 & 32 \\
\hline
\end{tabular}

U stranim publikacijama radovi iz Medijskih istraživanja dobili su ukupno 57 citata. Najviše citata zabilježeno je u slovenskom časopisu Javnost - The Public (12), engleskom časopisu Understanding Media Policies (5) te američkom časopisu Journalism (4) i engleskom Journalism Studies (4). U ostalim časopisima Medijskim istraživanjima dodijeljeno je 3 ili manje citata. 
Tablica 8. Reference časopisa Medijska istraživanja u stranim publikacijama

\begin{tabular}{|l|c|c|}
\hline \multicolumn{1}{|c|}{ Strane publikacije } & Broj radova & Broj citata \\
\hline Javnost - The Public (E+S)* & 9 & 12 \\
\hline Understanding Media Policies & 1 & 5 \\
\hline Journalism Studies & 2 & 4 \\
\hline Journalism & 2 & 4 \\
\hline Annales - Anali za istarske in mediteranske studije & 3 & 3 \\
\hline Asian Journal of Communication & 3 & 3 \\
\hline Finding the Right Place on the Map & 2 & 3 \\
\hline East European Politics and Societies & 1 & 3 \\
\hline Journal of Mass Media Ethics & 2 & 2 \\
\hline Convergence & 1 & 2 \\
\hline Industrial Management \& Data Systems & 1 & 2 \\
\hline B E Journal of Economic Analysis \& Policy & 1 & 1 \\
\hline Communications & 1 & 1 \\
\hline Discourse processes & 1 & 1 \\
\hline European Journal of Communication & 1 & 1 \\
\hline Genere and the (Post-)Communist Woman & 1 & 1 \\
\hline Geodetski vestnik & 1 & 1 \\
\hline International Journal of Cultural Studies & 1 & 1 \\
\hline International Journal of Digital Television & 1 & 1 \\
\hline Logos Universality Mentality Education Novelity & 1 & 1 \\
\hline LUMEN 2013) & 1 & 1 \\
\hline Media, Power and Empowerment & 1 & 1 \\
\hline New Media \& Society & 1 & 1 \\
\hline Rethinking Journalism & 41 & 57 \\
\hline Social, Sciences and Society & 1 & 1 \\
\hline European Journalism Education & 1 & 1 \\
\hline Ukupno & 1 & 1 \\
\hline
\end{tabular}

* Napomena: Časopis Javnost - The Public u tri reference u WoSCC-u navodi engleskog izdavača, a u šest slovenskog. 
Analizom autora koji su citirali časopis Medijska istraživanja utvrđeno je da je 51 autor u 68 radova citirao radove iz časopisa Medijska istraživanja. U 27 domaćih časopisa i zbornika 27 autora citiralo je radove iz Medijskih istraživanja, a u 24 strane publikacije 39 autora. Usporedbom autora Medijskih istraživanja s autorima koji su ih citirali utvrđeno je da je 72,5\% autora koji nemaju nijedan rad objavljen u Medijskim istraživanjima te $27,5 \%$ autora koji imaju objavljene radove u proučavanom časopisu. Taj podatak mogao bi biti dobar pokazatelj prilikom promatranja časopisa od strane Clarivate Analyticsa za eventualni ulazak u njihove citatne indekse, odnosno, za početak, u njihovu novu bazu Emerging Sources Citation Index (ESCI) koja se pojavila 2015 godine.

Časopis Medijska istraživanja indeksiran je u citatnoj bazi Scopus od 2011. godine. Scopus, danas najveća bibliografska i citatna baza podataka koja daje podatke o citiranosti pojedinih autora i radova, analizira časopise te za njih, kao i za autore, izračunava $h$-indeks. Za časopise na svojim stranicama daje i podatak o SJR-indikatoru te podatak o SNIP-faktoru. ${ }^{34}$ U razdoblju od 2011. do 2015. u časopisu Medijska istraživanja bilo je ukupno 112 kategoriziranih radova i priloga (66 radova i 46 priloga), a Scopus je iz tog razdoblja indeksirao ukupno 71 jedinicu. Indeksirani su svi kategorizirani radovi, osim jednog rada koji je vjerojatno omaškom preskočen. To je rad iz broja 1 2013. godine. Prema kategorizaciji indeksiranih jedinica u bazi podataka Scopus, iz časopisa Medijska istraživanja indeksirano je 60 radova, 6 uvodnika, 4 prikaza i jedan kratki pregled.

Baza indeksira sve kategorizirane radove, osim ako se dogodi da koji rad greškom izostane. U tom slučaju uredništvo časopisa ili autor izostavljenog rada treba o propustu obavijestiti Scopus. Osim kategoriziranih radova, Scopus indeksira i pojedine priloge.

Za sve indeksirane jedinice Scopus daje podatke o citiranosti. U vrijeme pretraživanja časopisa Medijska istraživanja (srpanj 2016.), od 71 indeksiranog rada citirano je njih 16. Tri rada citirana su 4 puta, a tri rada 3 puta. Četiri rada dobila su 2 citata. H-indeks iznosi 3, ukupna je citiranost tih 16 jedinica 29, a bez samocitata 25. Za časopis Medijska istraživanja, tj. za indeksirane radove, Scopus daje podatke o JR- i SNIP-indikatoru u kojima se primjenjuju podatci o citiranosti iz Scopus-a. Prema Scimago Journal \& Country Ranku časopis Medijska istraživanja svrstan je u područje društvenih znanosti (u kategorije Communication i Sociology and Political Science).

JCR (Journal Citation Reports) je časopise svrstane u određene predmetne kategorije podijelio u kvartile (Q1-Q4) prema visini IF-a. Časopis koji pripada u područje kvartila Q1 prema visini svog IF-a pripada među $25 \%$ časopisa s najvišim IF-om unutar skupine časopisa koji su svrstani u to predmetno područje. IF za određenu godinu jednak je razlici između zbroja citata dobivenih te određene

34 Isto, str. 42. 
godine za dvije prethodne godine i zbroja objavljenih radova u prethodne dvije godine. ${ }^{35} \mathrm{Na}$ osnovi tih parametara, tj. prema citatima dobivenim 2016. godine za radove objavljene 2015. i 2014. godine, za ilustraciju je izračunat približni IF za 2016. godinu. Ako bismo časopis Medijska istraživanja uvrstili u JCR-SS, kategoriju društvenih znanosti Communication, tada bi on prema izračunatom IF-u od 79 časopisa uvrštenih u to područje zauzeo posljednju poziciju s IF-om 0,147 te bi to odgovaralo kvartilu 4. Kad bi se isključili samocitati, IF bi iznosio 0,06 .

$$
\text { IF za 2016. godinu }=\begin{aligned}
& \text { broj citata } 2015=0 \\
& \text { broj citata } 2014=5
\end{aligned} \quad \begin{aligned}
& \text { broj radova } 2015=12 \\
& \text { broj radova } 2014=22
\end{aligned}=0,147
$$

Također, Scopus daje podatak o kvartilima u koje pripada određeni časopis unutar skupine kojoj pripada. Prema podatcima iz Scopusa, časopis Medijska istraživanja za 2014. godinu pripada među $75 \%$ časopisa u svojim predmetnim skupinama, tj. u Q3. 2015. godine prema podatcima SJR-a ulazi u Q4 s indikatorom SJR 0,124, s kojim od 277 časopisa u kategoriji Communication zauzima 208. mjesto. U kategoriji Sociology and Political Science od 951 časopisa zauzima 748. mjesto te također ulazi u Q4, promatrano u srpnju 2016.

\section{Zaključak}

Časopis Medijska istraživanja namijenjen je medijskim proučavateljima, profesorima i studentima, medijskim profesionalcima i kulturnoj javnosti koju zanimaju suvremene političke, ekonomske i kulturne promjene društva u dimenziji medija. Cilj i svrha časopisa jest pridonijeti razvoju teorije novinarstva u Hrvatskoj, omogućiti svima koji se praktično ili teorijski bave medijima publiciranje radova na jednome mjestu, rezultate istraživanja učiniti lakše dostupnima domaćim i stranim proučavateljima medija te razvijati kulturu medijskog komuniciranja. Bibliometrijskom analizom dobiveni su rezultati prema kojima je časopis u svom dvadesetjednogodišnjem kontinuiranom izlaženju objavio 276 kategoriziranih radova, od čega su najzastupljeniji izvorni znanstveni radovi (46 \%), zatim slijede stručni radovi (18,5\%), pregledni radovi (14,9 \%), izlaganja sa skupova $(12,3 \%)$, prethodna priopćenja $(6,2 \%)$, preneseni članci $(1,1 \%)$ te prevedeni radovi (1,1\%). Jezik objavljenih članaka uglavnom je hrvatski (60,5\%) ili strani jezik. Časopis je za objavljivanje znanstvenih radova zanimljiv ponajprije znanstvenicima iz Hrvatske (59,8 \%).

35 InCites: Journal Citation Reports (JCR). [citirano: 2017-07-20].Dostupo na https://jer-incites-thomsonreuters-com.ezproxy.nsk.hr/JCRJournalHomeAction.action?year=\&edition=\&journal=. 
Svoju vidljivost povećao je osiguravanjem pristupa cjelovitim tekstovima objavljenih radova, dostupnim preko Portala znanstvenih časopisa Republike Hrvatske - Hrčak (http://hrcak.srce.hr/?lang=hr) od vol. 6 (2000), br. 1. U Hrčak je uključen 2. studenog 2007. godine. Udio ukupne citiranosti časopisa Medijska istraživanja, proučavane u WoSCC-u, u stranim je časopisima znatan, pa čak i veći nego u domaćim časopisima. Citatna analiza časopisa od početka izlaženja pokazala je da citati u većini slučajeva potječu od autora koji ne objavljuju u časopisu Medijska istraživanja. Analiza samocitata, koja uključuje sva godišta časopisa, pokazala je da bi udio samocitata mogao biti u okvirima koji su prihvatljivi za promatranje i ulazak časopisa u kolekciju WoSCC, citatni indeks Emerging Sources Citation Index (ESCI).

\section{LITERATURA}

Borić, V.; M. Strujić. Bibliometric analysis of Acta stomatologica Croatica: 1987-2006. // Acta stomatologica Croatica 40, 4(2006), 345-355. Dostupno i na: http://hrcak. srce.hr/index.php?show=clanak\&id_clanak_jezik=17935 [citirano: 2016-10-05].

Borić, V. Analiza citata radova objavljenih u časopisu Acta stomatologica Croatica zabilježenih u bazi podataka Web of Science. // Acta stomatologica Croatica 42, 2(2008), 123-139. Dostupno i na: http://hrcak.srce.hr/index.php?show=clanak\&id_clanak_ jezik=40800 [citirano: 2016-10-05].

Brajenović-Milić, B. Bibliometrijski pokazatelji znanstvenog odjeka autora i časopisa. // Medicina Fluminensis 50, 4(2014), 425-432. http://hrcak.srce.hr/index.php?show=clanak\&id_clanak_jezik=191730 [citirano: 2016-10-15].

Dukić, Z. Mjesto sociologije u sistemu znanosti; Citatna analiza triju domaćih socioloških časopisa. // Revija za sociologiju 21, 3(1990), 455-465. Dostupno i na: http:// hrcak.srce.hr/index.php?show=clanak\&id_clanak_jezik=228892 [citirano: 201610-6].

Endersby, J.W. Collaborative research in the social sciences: multiple autorship and publication credit. // Social Science Quarterly 77, 2(1996), 375-392.

Eom, S. Author cocitation analysis: quantitative methods for mapping the intellectual structure of an academic discipline. Hershey ; New York: Information Science Reference, 2008.

Feinberg, G. ; B. Watnick ; A. Sacks. Solo vs. collaborative research in the social sciences and higher education: unraveling the realities of male-female research publication patterns in the context of gender politics and social justice issues. // Journal of Multidisciplinary Research 3, 3(2011), 47-63. 
Hebrang Grgić, I. Kriza izdavaštva znanstvenih časopisa. // Vjesnik bibliotekara Hrvatske 47, 1/2(2004), 87-94. Dostupno i na: http://www.hkdrustvo.hr/vbh/broj/86 [citirano: 2016-10-21] .

Hirsch, J.E. An index to quantify an individual's scientic research output. // Proc Natl Acad Sci USA,102, 46 (2005), 16569-16572. Dostupno i na: http://www.pnas.org/ content/102/46/16569.full.pdf [citirano: 2016-7-19].

Iglič, H.; P. Doreian ; L. Kronegger; A. Ferligoj. With whom do researchers collaborate and why? // Scientometrics 112(2017), 153-174.

InCites: Journal Citation Reports (JCR). [citirano: 2017-07-20]. Dostupno na: https:// jcr-incites-thomsonreuters-com.ezproxy.nsk.hr/JCRJournalHomeAction.action?year=\&edition $=\&$ journal $=$

Jokić, M. ; K. Zauder ; S. Letina. Karakteristike hrvatske nacionalne i međunarodne znanstvene produkcije u društveno-humanističkim znanostima i umjetničkom području za razdoblje 1991-2005. Zagreb : Institut za društvena istraživanja, 2012.

Jokić, M. Bibliometrijski aspekti vrednovanja znanstvenog rada. Zagreb: Sveučilišna knjižara, 2005.

Jokić, M. ; K. Zauder. Bibliometrijska analiza časopisa Sociologija sela/Sociologija i prostor u razdoblju 1963.- 2012. // Sociologija i prostor 51, 2(2013), 331-349. Dostupno i na: http://hrcak.srce.hr/index.php?show=clanak\&id_clanak_jezik=161510. [citirano: 2016-6-18].

Jokić, M. ; V. Borić. Znanstvena aktivnost na području botanike mjerena kroz časopis Acta Botanica Croatica. // Acta botanica Croatica 51, 1(1992), 169-176. Dostupno i na: http://hrcak.srce.hr/index.php?show=clanak\&id_clanak_jezik=235620 [citirano: 2016-6-18].

Jokić, M. H-indeks kao novi scientometrijski indikator. // Biochemia Medica 19, 1(2009), 5-9. Dostupno i na: http://hrcak.srce.hr/index.php?show=clanak\&id_clanak_jezik=51302 [citirano: 2016-7-19].

Krajna, T. ; J. Petrak. Bibliometric characteristics of the journal Strojarstvo in the Period 1992-2001. // Strojarstvo: časopis za teoriju i praksu u strojarstvu 46, 1-3(2004), $19-23$.

Macan, B. ; J. Petrak. Bibliometrijski pokazatelji za procjenu kvalitete znanstvenih časopisa. // Hrvatski znanstveni časopisi : iskustva, gledišta, mogućnosti. Ur. Ivana Hebrang Grgić. Zagreb : Školska knjiga, 2015.

Martek, A. ; S. Šute. Bibliometrijska analiza časopisa Arhivski vjesnik u razdoblju od 2001. do 2009. // Arhivski vjesnik 53, 1(2010). 165-176. Dostupno i na: http://hrcak. srce.hr/index.php?show=clanak\&id_clanak_jezik=93686 [citirano: 2016-7-19].

Švenda Radeljak, K. Journal Social Work: the first decade (1960-1969). // Ljetopis socijalnog rada 13, 1(2006), 115-132. Dostupno i na: http://hrcak.srce.hr/index.php?show=clanak\&id_clanak_jezik=11447 [citirano: 2016-6-5]. 
Švenda-Radeljak, K. Revija za socijalnu politiku- petnaest godina kontinuiranog izlaženja (1994.-2008.). // Revija za socijalnu politiku 17, 1(2010), 155-170. Dostupno i na: http://hrcak.srce.hr/index.php?show=clanak\&id_clanak_jezik=75229 [citirano: 2016-6-8].

Tella, A. ; A. O. Issa. Library and information science in developing countries: contemporary issues. Hershey : Information Science Reference, 2012.

Vejmelka, L. ; K. Švenda-Radeljak. Ljetopis socijalnog rada (1994.-2013.): dvadeset godina kontinuiranog izlaženja. // Ljetopis socijalnog rada 21, 2(2014), 313-333. Dostupno i na: http://hrcak.srce.hr/index.php?show=clanak\&id_clanak_jezik=193152 [citirano: 2016-7-12].

Vrana, R. Vrednovanje znanstvenog rada. // Vjesnik bibliotekara Hrvatske 54, 1-2(2011), 172-192. Dostupno i na: http://www.hkdrustvo.hr/vbh/broj/103 [citirano: 2016-7$15]$.

Zabajn Bogut, A. ; T. Krajna. Trideset godina časopisa Polimeri: bibliometrijske značajke kategoriziranih radova. // Polimeri 32, 2(2011), 81-87. Dostupno i na: http:// hrcak.srce.hr/index.php?show=clanak\&id_clanak_jezik=112463 [citirano: 2016-6$15]$.

Zauder, K. Razvoj sciontometrije praćen kroz časopis Scientometrics od početka izlaženja 1978. do 2010. godine: doktorski rad. Zagreb : Filozofski fakultet Sveučilišta, 2014.

Zgrabljić Rotar, N. Medijska istraživanja i medijska disciplina od 1995. do 2005. Zagreb: Doron, 2005. 